\title{
I. Osmotic experiments on mixtures of alcohol and water
}

\section{P.S. Barlow B.Sc.}

To cite this article: P.S. Barlow B.Sc. (1905) I. Osmotic experiments on mixtures of alcohol and water , Philosophical Magazine Series 6, 10:55, 1-12, DOI: 10.1080/14786440509463338

To link to this article: http://dx.doi.org/10.1080/14786440509463338

曲 Published online: 16 Apr 2009.

Submit your article to this journal $\pi$

Џ Article views: 2

Q View related articles $\longleftarrow$

Citing articles: 3 View citing articles 5 


\title{
PHILOSOPHICAL MAGAZINE
}

\author{
AND \\ JOURNAT, OF SCIENCE.
}

[SIXTH SERIES.]

JUL Y 1905.

I. Osmotic Experiments on Mixtures of Alcohol and Water, By P. S. BarLow, B.Sc. (Vict.), St. John's College, Cambridge*.

THE experimental work of this paper was undertaken by 1 way of examining a curious and unexpected result obtained by S. U. Pickering $\dagger$ in an osmotic experiment with propyl alcohol. The most recent estimate of the importance of this experiment as bearing on the theory of the action of the membrane in osmotic phenomena is given by W. C. D. Whetham $\ddagger$.

The following is a quotation taken from a letter written by Pickering to 'Nature,' dealing with the hydrate theory of solution $\S$. It serves here the double purpose of describing his experiment and giving his own estimate of its value in supporting the hydrate theory. He writes:- "On the other (the hydrate) side we have two experiments, which wouid seem to be conclusive, but which the dissociationists have hitherto thought fit to ignore.

"Osmotic pressure, they hold, is dne to the quasi-gaseous

* Communicated by Professor J. J. Thomson, F.R.S.

$\dagger$ Ber. Deut. Chem. Z7es. xxiv. p. 3639 (1891), and "Solution," Art. ii., Watt's Dict. of Chem.

I Whetham, 'Theory of Solution,' pp. 96,97.

$\$$ Nature, lv. p. 223.

Phil. Mag. S. 6. Vol. 10. No. 55. July 1905. 
pressure of the solvent and dissolved substance acting on a diaphragm, which, being permeable to the solvent only, renders the pressure of the dissolved substance inoperative, and hence causes the total operative pressure of the solution to be that of only the solvent present in it. Now, I have shown that if we take a solution such as that of propyl alcohol in water, and place it in a semipermeable vessel surrounded br water, the latter will pass through towards the solution, ergo, the vessel is permeable to water but impermeable to the alcohol; but if the same ressel with its same contents is surrounded by propyl alcohol, it is the alcohol that passes through towards the solution, ergo, the vessel is permeable to the alcohol, but not to the water..... The obvious conclusion to draw from this experiment is, that it is the solution. and not either of the substances separately, to which the membrane is impermeable, and this is just what we should anticipate on the hydrate theory, the molecules of hydrates. being necessarily larger than those of their constituents." The experiment is thus accepted as a 'crucial' one.

The experimental work, of which a short account is given in this paper, shows that the observation of an increase in the osmotic pressure after the cell is placed in the alcohol is correct, but that it is not due to an inflow of alcohol. Had more time been given to the experiment, it would have been found that this increase is not permanent as when the cell is in water. The permanent result is an outflow from the cell into the alcohol. And further : had the cell containing the solution been placed by Pickering again in water, he would most likely have found a decrease in pressure; and obviousiy the outflow causing it would have been the reverse of the anticipation based on the hydrate theory as above quoted. The explanation of what are here called "temporary" rise and fall (or inflow and outflow) is given after some account of the experiments.

\section{The Cells.}

It is not intended to give here a full account of the preparation of the cells. This was by far the most tedious part of the work. That some cells should prove useful and others prove failures, after exactly the same treatment, seems only to be accounted for by the presence of flaws within the pot. The membrane used was that of copper ferrocyanide obtained by diffusion. Of the thirty-one cells used in the preparation, fifteen proved sound. Of the others, their failure 
was generally due to a fault within the cell-wall, but not always; sometimes the leak was through the glass at the joint being strained or through the joint itself.

The cells were very hard and close-grained, having walls between $\cdot 4 \mathrm{~cm}$. and $\cdot 5 \mathrm{~cm}$. thick. Their internal length was about $6.5 \mathrm{~cm}$, and their internal diameter $1.6 \mathrm{~cm}$. A few cells of more porous clay and slightly thinner walls, kindly given by Mr. Whetham, were also used and proved verv serviceable.

The cell was prepared by washing in dilute alkali and then in dilute hydrochloric acid. It was then washed and boiled in several changes of distilled water and allowed to become nearly dry. Close-fitting glass tubing was ground into the end of the cell by means of wet emery-powder, and was fixed by litharge and glycerine cement. This hardens to a mass apparently unaffected by alcohol. This cement is rather porous, and any flaw in it may make it impossible to obtain a sound membrane. There is always the same risk of failure dus to want of uniformity in the cells themselves. The joint obtained by using sealing-wax is more suitable for formation of the membrane, but had to be abandoned on account of the ease with which it is attacked by alcohol. Of the cells with sealing-wax joints a much larger percentage proved sound.

The air in the pores of the cell was driven out by means of electric osmose and afterwards by placing under the waterpump and drawing freshly boiled distilled water, still slightly warm, through the cell-walls. Its own volume of water was drawn through several times. In the case of the more porous cells, drawing water through in this way seemed sufficient. The cell was then placed in copper-sulphate solution and was filled with potassium ferrocyanide soiution. With the harder cells, ten to fourteen days in these solutions seemed necessary for the formation of a useful membrane. The cell was then fitted with a gauge and tested by a sugar solution of known strength.

In the gauge attachments there were two T-pieces arranged. in $H$ form. Below one vertical portion was the cell ; below the other the gauge was fixed. In this way the cell and gauge could readily be washed out without detaching the gauge. The opening immediately above the cell was closed by thick-walled rubber tubing wired over a flange on the glass, and a screw-clip. The opening above the gauge was closed by fusing the drawn-out glass. The rubber tubing made it possible to add pressure by means of a pump, and to 
relieve slowly any pressure set up during an experiment. The volume of the air enclosed within the cell was very small, so that any change in the volume of the cell's contents immediately moved the gauge-level. The bore of the gaugetubing was small, in the largest having a volume of 0358 c.c. per cm. length.

\section{The Experiments.}

In the experiments with the alcohol solutions, no attempt was made to get the actual values of the osmotic pressures. In most cases, the solutions were too strong and generally the pressure was not allowed to reach values greater than those for which the cell had previously been tested, thus keeping the experiment within the known limits of the cell's strength. However, in more than one case, a cell left overnight got up a pressure large enough to burst the rubber tubing or force it over the flange, below which it was wired. The cells still remained sound. What pressure the best cells could bear before breaking down is not known; and for obvious reasons it has not been sought.

Experiments were performed with varying strengths of solutions, going up from 15 per cent. alcohol by steps of 5 per cent. to 70 per cent. Strengths below and above these limits were also used, all with the same result. This gradual increase of the strength of the solution was thought to be advisable, because it seemed not unlikely that when the alcohol was in great excess the sign of the osmotic current might change. In other words, the alcohol might become the solvent and the water the solute. This, however, was not found even when the water was present in very small quantity indeed.

In these experiments, where water was always present, the alcohols were not further rectified. They were supplied to the laboratory as pure and so used. The specific gravity (compared to water at $4^{\circ} \mathrm{C}$.) of the ethyl alcohol was $\cdot 7948$ at $16^{\circ} \mathrm{C}$.; that of the methyl alcohol, ${ }^{7} 740$ at $18^{\circ} \mathrm{C}$.; that of the propyl alcohol, $\cdot 8274$ at $14^{\circ} \cdot 8 \mathrm{C}$. This last was taken some time after the experiments were completed, and is therefore likely to be much higher than when first used.

On removing from one liquid to another, the cells were dried by folding in filter-paper. 
Table I.-Cell $\beta$. Ethyl-alcohol solution. Strength for maximum contraction.

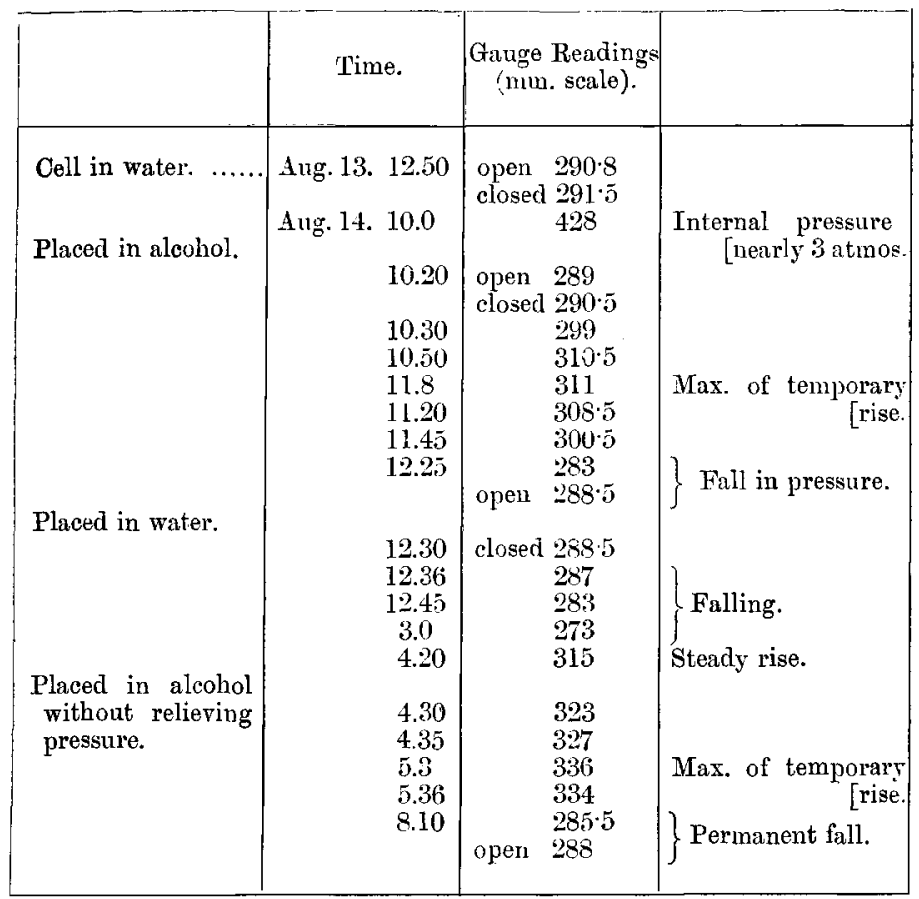

Table II.-Cenll XXIV. Solution of Propyl Alcohol: 60 c.c. of alcohol in 100 c.c. of solution.

\begin{tabular}{|c|c|c|c|}
\hline & Time. & Gauge Readings & \\
\hline $\begin{array}{l}\text { Cell in water. } \\
\text { Opened and placed } \\
\text { in propyl alcohol. } \\
\text { Placed in water. }\end{array}$ & $\begin{array}{cc}\text { Monday } 12.35 \\
2.20 \\
4.20 \\
\\
4.28 \\
4.34 \\
5.17 \\
8.0 \\
\text { Tuesday } 4 . .1 . \\
\\
9.45 \\
11.20 \\
12.10 \\
5.5 \\
5.20\end{array}$ & \begin{tabular}{|c|c|} 
closed 268 \\
303 \\
$349 \cdot 1$ \\
closed $271 \cdot 6$ \\
$276 \cdot 4$ \\
300 \\
269 \\
Beyond the bend \\
of the gauge-tube \\
\\
$274 \cdot 5$ \\
$270 \cdot 2$ \\
270 \\
330 \\
$336 \cdot 2$ \\
open \\
277
\end{tabular} & $\begin{array}{l}\text { Steady normal rise. } \\
\text { Rising. } \\
\text { Falling. } \\
\text { Showing consider- } \\
\quad \text { [able outflow. } \\
\text { \{Temporary fall. } \\
\{\text { Rapidly rising. }\end{array}$ \\
\hline
\end{tabular}




\section{TABLe III.}

CELL XXIV.-The cell was first soaked in methyl alcohol. The solution consisted of 49 c.c. of methyl alcohol made up to 50 c.c. with water: i.e., nearly 24 molecules of alcohol to 1 of water.

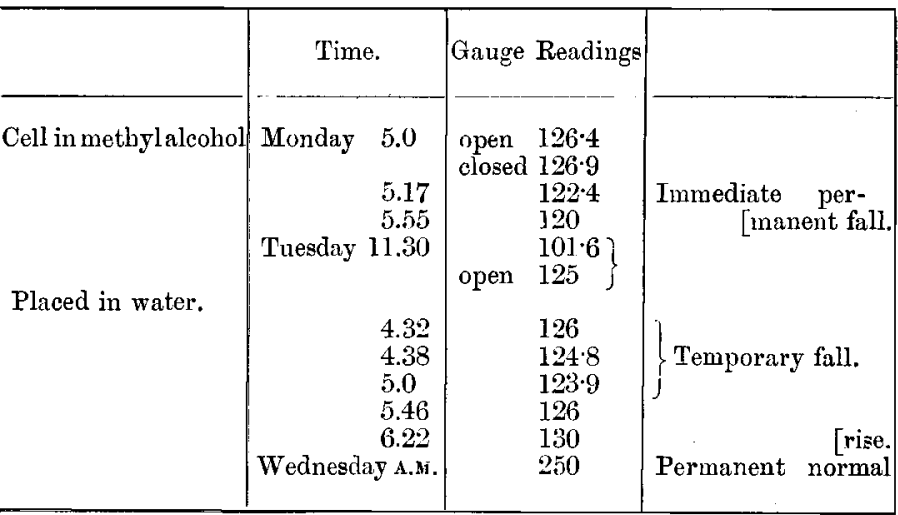

\section{TABLE IV.}

CELL XII. - In this case the solution was outside the cell and and alcohol inside.

Solution of ethyl alcohol: $60 \mathrm{grs}$, alcohol in 100 c.c. solution.

\begin{tabular}{|c|lc|c|c|}
\hline & & Time. & $\begin{array}{c}\text { Gauge } \\
\text { Readings. }\end{array}$ & \\
\hline Cell standing in & Thursday & 12.20 & 289 & \\
the solution. & & 4.35 & $292 \cdot 6$ & \\
& Friday & 10.0 & 3055 & \\
& Saturday & 11.45 & 323 & \\
& Monday & 10.40 & 354 & \\
& Tuesday & 10.0 & 361 & Shows permanent rise and \\
& Wednesday 10.20 & 373 & inflow from the solution. \\
\hline
\end{tabular}

After the above experiment, the alcohol was withdrawn and the cell was filled with water. This would give a weak solution of alcohol (but not very weak, owing to small capacity of cell) inside. During the next 24 hours there was a large decrease in the internal pressure, indicating a current from the weaker to the stronger solution. 
The above tables of results are typical of those obtained from experiments with other solutions and with other cells. Considering the results in Table I., we find a rapid rise of pressure when the cell is surronnded by water. The normal rise of pressure is spoken of as "permanent" for the purposes of this paper.

When placed in alcohol, cell $\beta$ showed an increase of pressure, the gauge rising through $20.5 \mathrm{~mm}$. in 48 minutes. There was no further rise. The level then fell steadily. The above rise was "temporary": this fall is " permanent," that is, it would have continued until the liquids on both sides of the membrane had the same composition, or until further outflow was stopped by the difference between the internal and external pressures. That this outflow was permanent in this sense, and not temporary, was readily shown by repeatedly opening and closing the cell while it remained in the alcohol; there was always a fall of the gauge-reading. It was necessary to open the cell at intervals to avoid the mercury being sucked back beyond the bend of the gauge.

In this connexion the experiment of Table IV. is important. The arrangement in this case is the reverse of having the solution inside and the alcohol outside. The osmotic current, which in the latter was the permanent outflow, now becomes a steady inflow and may be allowed to show itself over a long interval of time. The rate of rise of pressure is much slower than in the case when pure water is outside, as would be expected. The resuits given in Table IV. are spread over a week. Obviously, if the current can only be from the single liquid to the mixture, as expressed in Pickering's account, then results like those of Table IV. would be impossible.

When the cell was placed in water after being removed from the alcohol, there was a temporary fall in all cases. In Table I. this fall continued for about three hours, and was succeeded by a steady increase of pressure. On being placed in alcohol again without relieving the internal pressure, there was a temporary rise as before ; but this time the rise was less. The internal pressure opposed the temporary inflow.

The case in Table III. is slightly different. The cell was first soaked in the alcohol, and then the solution was added. The cell being in alcohol, there was no temporary rise; the permanent fall began at once. When placed in water, the temporary fall was that usually found.

All the experiments point to the conciusion that the water tends to cross the membrane in that direction which will promote its equal distribution on both sides.

This conelusion has been put to the following severe test. 
A cell was soaked in methyl alcohol, the onter vessel being closed by a cork covered with melted wax. With changes of alcohol, both sides were obtained osmotically similar; that is, the closed cell showed neither increase nor decrease of pressure. This being so, the cork of the outer vessel was fitted with a water manometer. The absorption of the water vapour by the alcohol caused a slow but steady increase of the internal pressure. In the case of ethyl alcohol exposed to the air of the laboratory, the same result was obtained. In these cases, it might have been thought on a priori grounds that the alcohol was in so very large excess, that it could have been regarded as dissolving the water. Experimentally, the water acted as the solvent (in the osmotic sense).

The explanation of the temporary effects is very simple. After the preparation of the cell in the ordinary way, the cell-wall is soaked with water. When the solution is within the cell, the membrane soon gets into what may be called the osmotic condition; that is, the condition of having water at its outer surface, and solution at its inner surface. The normal inflow of water takes place.

When placed in alcohol, the outer face of the membrane remains in contact with water, until the alcohol diffuses through 2 or $3 \mathrm{~mm}$. of the small pores of the pot. While this diffusion is going on, the water in contact with the membrane is passing into the cell under normal osmotic conditions. This gives the temporary rise. This inflow of the water between the outside alcohol and the membrane helps the alcohol to reach the membrane in a shorter time than would be required if the water within the pores were stationary. When the alcohol is in contact with the membrane, the fall in pressure begins. In support of this explanation there is the absence of any temporary rise in the experiment of Table III.

This explanation also accounts for the temporary fall when the cell is taken from the alcohol and is placed in water. Now there is a layer of alcohol in the pot between the membrane and the outside water. So long as this remains there is an outflow. When the water reaches the membrane, the permanent and normal rise of pressure begins.

If this way of accounting for these temporary effects be the true one, it follows that, if the cell remain in the water until the pressure set up is at its maximum value and be then placed in alcohol, there will be no temporary rise. The osmotic equilibrium will last so long as water is in contact with the outer face of the membrane ; and further, since there is now no inflow, the alcohol will have to diffuse through a layer of water whose thickness is not reduced by any passage 
on Mixtures of Alcohol and Water.

through the membrane as before. The interval of time between placing the cell in alcohol and the commencement of the fall of pressure will be greater than that in the ordinary experiments.

The results given in Tables $V$. and $V I$. show this very clearly. TABLE V.

CeLL XVI.-Solution of Ethyl Alcohol : 25 c.c. of alcohol in 100 c.c. solution.

Cell in water till the gauge-reading was constant (after 3 days).

\begin{tabular}{|c|c|c|c|}
\hline & Time. & $\begin{array}{c}\text { Gauge } \\
\text { Readings. }\end{array}$ & \\
\hline $\begin{array}{l}\text { Cell in water. } \\
\text { Cell dried and placed in } \\
\text { alcohol without opening. } \\
\text { Placed in water without } \\
\text { opening. }\end{array}$ & \begin{tabular}{|cc} 
Friday & 5.0 \\
& \\
& 5.2 \\
& 5.7 \\
& 5.17 \\
For every & 5 min \\
until & 6.12 \\
& 7.55 \\
& 9.0 \\
& \\
Saturday & 10.30 \\
Monday & 8.50 \\
& 11.10 \\
& \\
& 12.30 \\
& 5.15 \\
Tuesday & 10.0
\end{tabular} & $\left.\begin{array}{|c}389 \\
389 \cdot 2 \\
389 \cdot 1 \\
389 \\
\\
389 \\
389 \\
388 \\
376 \\
307 \\
296 \cdot 8 \\
290 \cdot 3 \\
268 \\
324 \\
\text { open } 291\end{array}\right\}$ & $\begin{array}{l}\text { Maximum. } \\
\text { The small rise due to } \\
\text { handling the cell } \\
\text { during the drying. }\end{array}$ \\
\hline
\end{tabular}

\section{TABLe VI.}

Celu XXIII.-Solution of Propyl Alcohol: 20 c.c. of alcohol in 100 c.c. of solution.

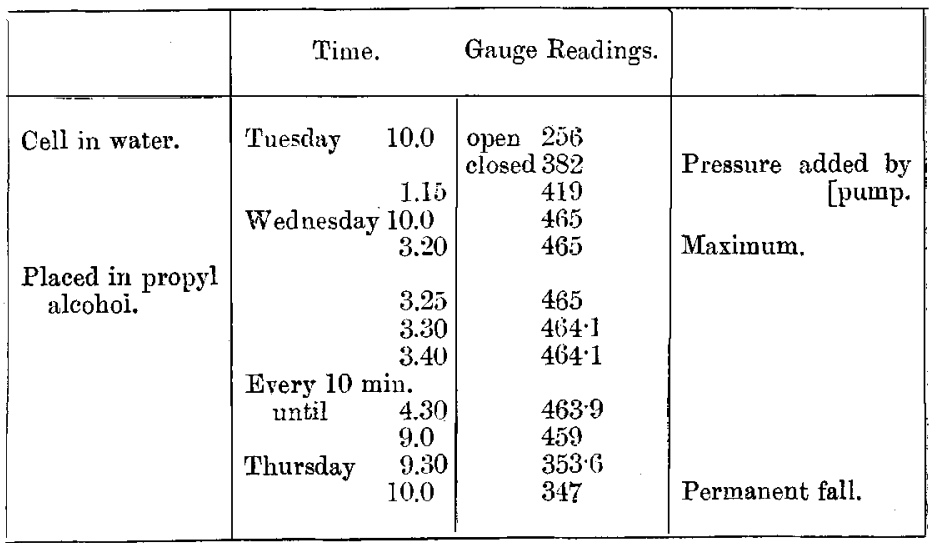


When placed in water after the above there was a temporary fall of nearly $80 \mathrm{~mm}$. succeeded by a large and steady rise.

In Table $V$. the time required for the permanent fall to set in is about four hours; in Table VI. probably less than four hours. In Table I. the fall began in a little more than half an hour : in Table II. the gauge had risen and fallen again below its starting point in less than four hours. In this way, therefore, the temporary effects seem satisfactorily accounted for, and the true explanation of Pickering's observations given.

These experiments have shown that what was claimed as a "crucial" experiment in support of the hydrate (as distinguished from the dissociation) theory of solution can no longer be claimed as such. Nevertheless it would not be a justifiable inference to conclude that therefore a hydrate theory of solution is untenable. A large amount of work has been done on the properties of solutions of various solventsamong other workers mention may be made of Fitzpatrick *, Lincoln $\dagger$, Schlundt $\ddagger$, H. C. Jones and Carroll $\$,-$-and all goes to show that the influence of the solvent is considerable and that some kind of complex of solvent and solute is formed. Some kind of "hydrate" theory seems necessary; but in this sense it must not be regarded as excluding dissociation.

It may justly be concluded that these experiments prove that the part played by the membrane in osmotic phenomena is not a sieve-like one. For in the experiments where the outside alcohol got its water by absorbing the aqueous vapour in the air above it, the ratio of the alcohol molecules to the water molecules must have been very large; hence it is very probable that each water molecule would be the centre of an aggregate of alcohol molecules, which is carried along with it. Everything really seems to be in favour of the pure alcohol getting through to produce a current from within outwards. For if we consider the alcohol within the cell, it has none of its molecules hampered by the aggregating influence of water molecules; and therefore on any theory accepting a quasi-gaseous pressure exerted by the liquids, there would be a larger number of effective alcohol molecules inside the cell. This would lead us to anticipate an outflow of alcohol from the cell; a decrease, instead of an increase,

* Phil. Mag. xxiv. p. 37t (Nov. 1887).

+ Journ. Phys. Chem. iii. p. 457.

† Ibid. vi. p. 159 .

$\S$ Amer. Chem. Journ. xxxii. 6 Dec. 1904, p. 521. 
of the pressure. In support of this there is the long-known fact that a copper ferrocyanide membrane is permeable to alcohol, though not in an osmotic sense*; and from experiments recently performed by the writer, there is evidence that, under mechanical pressure, alcohol gets through the membrane more easily than water. This removes the argument based on the larger molecular volume of alcohol, which might be put forward in favour of a sieve-like action. However, with all this in support of the alcohol passing outwards, we find an increase of the internal presstire; the water, though present in so small quantity, gets through the membrane.

Any form of hydrate theory assumes an attraction between the two kinds of molecules. This attraction is the result of what has been called "residual affinity" $\uparrow$, a conception since revived by Lodge $\ddagger$ and Traube $\S$. Its origin is most likely "chemical," and its action must be one of the causes of which osmotic pressure is the effect; most probably it is the cause. In consequence of this attraction there is mutual potential energy between the solvent and the solution. This tends to reach a minimum, and in doing so under the restrictions of an osmotic experiment, an opposing pressure is set up which hinders dilution and the consequent reduction of potential energv of solution.

I. Traube $\|$ has very recently put forward the theory that difference between the surface-tensions of the solvent and solution is the cause of the osmotic current; and that the latter will be from the liquid of weaker surface-tension. In connexion with this there is the experiment at the end of Table IV., where the current was from the weaker solution : that is, from the one with the greater surface-tension. In the same way, many similar experiments both with copperferrocyanide membrane and animal-parchment membranes are not in agreement with this theory. The only method of finally testing such a theory would be to use a membrane equally permeable in an osmotic sense to both liquids of the mixtures. The existence of such a membrane seems highly improbable.

In any adequate theory of osmotic pressure, the part played by the membrane must be taken into account. This necessary part is that the membrane must absorb that liquid

* Tamman, Ann. Phys. Chem. [2] xxxiv. p. 309.

+ Pickering, Ber. Deut. Chent. Ges. xxiv. p. 3629.

I 'Nature,'Ixx. p. 176.

$\$$ Phil. Mag. viii. (Aug. 1904) p. 162.

॥ Phil. Mag. viii (Dec. 1904) p. 708. 
which, in going through, forms the osmotic current *. On this point the work of Nernst $\dagger$ and Flusin $\ddagger$ may be referred to. During the last year the writer has been working on the osmotic pressure of ethyl-alcohol solutions with different membranes. One experiment may be mentioned here (it is not put forward as original). Pure alcohol and pure water were separated by a gutta-percha tissue, the water being within the cell. A large pressure was set up, sbowing an inflow from the alcohol to the water. With a copperferrocyanide membrane the direction is reversed. The cause of the current is the same in each case, namely, the mutual potential energy of solution of the liquids; the direction of the current is conditioned by the membrane.

The experimental work of this paper was carried out at the Cavendish I Laboratory. I wish to take this opportunity of thanking Prof. J. J. Thomson for his kindness during the progress of the work.

II. The Effect of a Surface-Film in Total Reflexion. By Robert A. Houstotn, M.A., B.Sc., Glasgow University 1851 Exhibition Scholar $\$ \|$.

T'T is well known that Fresnel's Laws for determining the phase and amplitude of a reflected or refracted light-wave from those of the incident wave have not been found to give the exact experimental result, when investigated with the most accurate experimental means. There is a difference between the calculated and observed results, greater than the experimental error. It is assumed in deriving Fresnel's laws, that at the surface where reflexion takes place the index of refraction changes discontinuously in going from the one medium to the other. The deviation from Fresnel's laws has been satisfactorily explained on the assumption that there is a "surface-film" between the two media. This surface-film can be regarded as a transition-layer; in which the index of refraction changes continuously from the value it has in the

* Since this paper was written, a similar view has been arrived at by Prof. Kahlenburg (Phil. Mag. Feb. 1905, p. 228) on similar lines of work.

$\dagger$ Zeit. Phys. Chem. vi. p. 37 (1890).

$\ddagger$ Comptes Rendus, exxxi. p. 1308 (Dee. 31, 1900).

\$ Communicated by Professir A. Gray, F.R.S.

II "Wirkuug einer Oberflächenschicht bei Total-reflexion," R. A. Houstoun, Göttinger Nachrichten, 1903, p. 352. "Ueber die Wirkun'. einer Oberflächenschicht bei Total-reflexion." R. A. Houstoun, Phys. Zeitsch, ift, vi. p. 208. 